\title{
A PROPOSAL FOR A TYPOLOGY OF SHARING ECONOMY
}

\section{MAIRA PETRINI}

Pontifícia Universidade Católica do Rio Grande do Sul (PUC-RS), Porto Alegre - RS, Brazil.

CÁSSIO STEDETN DE FREITAS

Project Management Institute (PMI-RS), Porto Alegre - RS, Brazil.

\section{LISILENE MELLO DA SILVEIRA}

Pontifícia Universidade Católica do Rio Grande do Sul (PUC-RS), Porto Alegre - RS, Brazil.

To cite this paper: Petrini, M., Freitas, C. S. de., \& Silveira, L. M. da S. (2017). A Proposal for a Typology of Sharing Economy. Revista de Administração Mackenzie, 18(5), 39-62. doi 10.1590/167869712017/administracao.v18n5p39-62 


\section{ABSTRACT}

Purpose: to propose a typology for sharing economy that allows the characterization and classification of its main forms of manifestation.

Originality/value: the theme that involves collaborative consumption and sharing economy has wide definitions with no clear establishment of boundaries between them. Part of that definition gap may occur because of the recent emergency of literature on sharing economy. Additionally, the fact that sharing economy and collaborative consumption are the newest buzzwords, several businesses started calling themselves as such.

Design/methodology/approach: from the review of the literature, 11 characteristics that describe the theme were identified. In the light of those characteristics, 72 collaborative consumption websites were analyzed, representatives of the 24 collaborative consumption categories proposed by Botsman and Rogers (2010).

Findings: three archetypes were identified: 1 . new business models represent the new players based on technological platforms, which are the core business of the company, and generate income by charging service fees; 2 . redesigned businesses are traditional market models redesigned to present time and price advantages to the consumer; 3. sharing by ideal is the archetype that best represents sustainable consumption alternative models.

\section{KEYWORDS}

Sustainability. Sharing economy. Collaborative consumption. Typology. Collaborative platforms. 


\section{INTRODUCTION}

Exaggerated consumption and a culture based on wasting are the main culprits for serious environmental problems that end up causing other growing problems, which include resource depletion. A possible solution to avoid the unnecessary use of resources is organized by sharing through exchanging, lending or even renting goods, giving people the same benefits of ownership. It refers to granting access over owning. Sharing economy emerges as a manifesto to hyper consumption, adopting disruptive collaborative practices. Such practices suggest market intelligence focused on sustainability and encompass multiple social dimensions, such as those involving values, practices and consumption habits, environmental awareness, quality of life, technological development, and economic and social perspectives (Heinrichs, 2013). Although its economic impact is still considered a mystery, sharing economy grows and deals with billions of dollars (Martin, 2016).

There is much consumption experience by means of sharing material assets, and frequently this sharing is aimed at increasing the usage of a product, thus reducing the amount of material produced, which is often discarded as a result of a single use (Mont, 2004). Belk (2010) links sharing to consumption, considering sharing as an act of distribution of what is ours to be used by others, or the act of receiving something from others for our own use. In this scenario, collaborative consumption emerges, becoming a large-scale phenomenon that already involves millions of users and presents itself as a profitable investment option for several companies. Collaborative consumption has grown in such a way that sharing has been described as a transformer of individual and local behavior, leading a movement capable of modifying traditional business models (Piscicelli, Cooper, \& Fisher, 2015). The rapid growth of this phenomenon comes largely by the explosion of platforms such as Uber and Airbnb, almost treated as the phenomenon itself.

Analyzing publications on sharing economy and collaborative consumption, Silveira, Petrini, and Santos (2016) identify definitions that are broad and unclear concerning the boundaries between collaborative consumption and shared economy, making room for studies that seek to better delimit interdependencies between the topics and a taxonomy for the area, and also to better specify their ways of structuring and acting in society. Part of this definition gap may be due to the recent emergence of sharing economy literature (Martin, 2016). In addition, there is the fact that sharing economy and collaborative consumption are the newest buzzwords and, 
therefore, countless businesses start to entitle themselves as such, without necessarily being them. The aim of this article is to better delimit and enhance the understanding of sharing economy and collaborative consumption, as well as to propose a typology for sharing economy that allows the characterization and classification of its main forms. To explore this objective, the academic literature was reviwed and 11 characteristics that describe sharing economy were identified. The analysis of 72 websites representing different categories of collaborative consumption helped us determine three archetypes: new business models, redesigned businesses and sharing by ideal, proposing our framework that organizes the diversity of emerging ever-faster business models under the umbrella of the so-called sharing economy. At the end, there is a reflection regarding the archetypes identified from the analysis of the determined definitions and the three archetypes.

\section{EXPLORING THE BOUNDARIES OF SHARING ECONOMY AND COLLABORATIVE CONSUMPTION}

Sharing is focused on exchanging gifts and goods; it is an alternative to private property. When sharing, two or more people enjoy the inherent benefits (or divide costs) of owning a shared object. It is possible to share physical objects such as a house or a car, as well as other more abstract ones, such as knowledge or relationships. In short, sharing implies voluntary lending, sharing, and use of resources that are, primarily, collectively owned (Belk, 2007). What is defined today as sharing economy is a socio-technical system established to exchange goods and services. However, much of what is described as sharing economy is not, in fact, sharing. Ownership transfer or compensation (monetary or otherwise) do not occur in pure sharing practices, for example (Kennedy, 2015). In order to be more precise regarding sharing, the author identifies three distinct narratives: sharing as an economy, as a scale distribution model, and as a method to intensify social relations. Distinguishing sharing this way demonstrates the contradictions and points of convergence among each of the narratives, which are often taken together as a single body of literature (Kennedy, 2015). That is, sharing economy has its roots in the concept of sharing, but with specific nuances that we seek to focus in this section. According to Schor (2014), sharing economy began in the 1990s with the emergence of websites that recirculate goods, such as eBay and Craigslist, representing what Kennedy (2015) identified as "sharing as an economy". 
The evolution of technology and the dissemination of social networks served as the basis for peer-to-peer transactions and the direct connection between consumers and producers (Gansky, 2011), i.e. a scale distribution model. Thus, two of the narratives proposed by Kennedy (2015) were identified: sharing as an economy and as a scale distribution model. Finally, sharing seen as a method to intensify social relations can be understood within the category that focused on sharing assets or space in order to enable production, rather than consumption (Schor, 2014), as coworking spaces.

Within this scenario, we can still find what is called collaborative consumption. This can be understood as a "slice" of the sharing economy whose focus is strictly related to the consumption issue. For Kennedy (2015), collaborative consumption is characterized, in essence, as the set of services that allows private and commercial owners of specific resources to make them available to others. According to Belk (2014), there are two different aspects about collaborative consumption: 1. collaborative consumption as those events in which one or more people consume economic goods or services together, in order to participate in activities with one or more people; 2. collaborative consumption as a transaction, which includes actions such as sharing, exchanging, lending, renting, and giving. Botsman and Rogers (2010) state that collaborative consumption is seen as sharing, exchanging, borrowing, exchanging, renting, and donating practices, reinvented by means of network technology on an unprecedented scale involving various actors within economy.

After five years of its original publication, Botsman (2015) says that companies in this segment have been expanding their actions on the Internet with community support. Thus, they initiate a continuous movement, which has been changing consumption, with reduced costs and quality perceived by consumers when they use digital platforms. As defined by Botsman and Rogers (2010) and Botsman (2015), two elements are clear: digital platforms and different actors (not only individuals, but also organizations). Another element identified in the concept of collaborative consumption is collective action.

Collaborative consumption is necessarily collective, whereas ordinary consumption may be a solitary activity that exists to privately please an individual. It is considered that collaborative consumption cannot be seen not only as simple commercial consumption, but also considers consumption practices as collective acts that encourage the creation of connections between the individual-private and the public-collective aspects of consumption. It also appears daily, structured in the community's 
subsistence activities (Laamanen, Wahlen, \& Campana, 2015). According Mohlmann (2015), individuals' actions are based on moral reasoning, seeking to maximize utility and save costs, or even minimize transaction costs. In this sense, individuals look for ways to collaborate with each other, and this is considered to be logical.

By exploring the boundaries between sharing economy and collaborative consumption, we have found in the literature what we will call two sharing models: one based on access and the other, on transfer. By the time private and commercial owners of specific resources make them available to others, it defines a sharing model based on access. It basically differs from the sense of perceived property (Bardhi \& Eckhardt, 2012), due to in the access there is no transfer of ownership or joint ownership when it comes to access: the consumer is only allowed to use the goods (Belk, 2010). Historically, access can be granted by joining clubs or organizations where various products can be shared. Access-based consumption differs from the traditional leasing process due to the possibility of being mediated solely via the Internet, becoming more collaborative and not always mediated solely by the market (Bardhi \& Eckhardt, 2012).

The other sharing model identified in academic literature is ownership transfer. It can happen from exchanging, which is an action that can denote sharing (as in the example of a community for exchanging books or toys) and adds some of the purposes of the act of giving. Similarly to sharing, giving a gift does not necessarily imply receiving something in exchange (act without reciprocity). However, even though many community members are clearly not interested in receiving something in return, in practice, it is observed that the benefit is mutual. Due to the simple fact it can be reciprocal, it constitutes sharing, which provides mutual benefits (Corciolani \& Dalli, 2014). Gift-giving usually happens on special occasions, such as ceremonies, parties or events. It is a reciprocal act, reinforcing the idea it can be considered as goods exchange (Corciolani \& Dalli, 2014). Thus, gift giving, as well as exchanging, is sharing, and it results in ownership transfer. Likewise, the act of giving, called gift giving, is a way of transferring ownership by sharing (Belk, 1976; Sherry Jr., 1983). Therefore, we have identified different types of sharing.

In short, sharing economy and collaborative consumption seem to be based on the same principle: sharing, whether it is based on access or transfer, reinventing behavior from traditional markets such as renting, lending and swapping, in an alternative form of economy, aiming at taking advantage from underused assets. Collaborative consumption seems to be within 
the sharing economy, delimiting more strongly as an environment where the acquisition and distribution of resources for consumption purposes is coordinated through a fee or other types of compensation. Finally, it is configured as digital platforms where participants or organizations manage their sharing activities themselves. Although it can occur without the mediation of technology, technology is what propels the emergence of the scale in sharing economy.

When the existing literature is analyzed in order to search for different typologies for sharing economy and collaborative consumption, we realize that the authors generally explore the concept as a whole, without focusing on classifications. Many researches use the specificity approach at some platform that allows sharing as if it were, per se, conceptually collaborative consumption on its own (or one of its types). A typology for collaborative consumption was proposed, where examples of collaborative consumption were classified into three specific types of systems (Botsman \& Rogers, 2010):

1. product service systems: they allow companies to offer products as a service instead of selling them as products. Goods that are private can be shared or rented. These systems aim to offer the benefits of products without the need of owning them;

2. redistribution markets: used or pre-owned goods are redistributed/ moved from a place where they are no longer needed to a place where there is need. In some markets, goods may be free. In others, goods are directly swapped or sold;

3. collaborative lifestyles: people with similar needs or interests come together to share and exchange less tangible assets such as time, space, skills and money. These exchanges happen mainly at the local level. Lifestyle sharing happens on a global scale, also through activities such as leases.

To differentiate more assertively consumption access, Bardhi and Eckhardt (2012) point out specific dimensions and explain them one by one. They are:

1. temporality: consumption, even when collaborative, sometimes allows long-term interactions that denote product ownership. This interaction is always temporary regarding access. Within this dimension, there are variations that can occur in two ways: access can be for a short time (such as a daily car rental or a hotel room) or it can be longitudinal, which lasts longer (by means of joining communities or clubs). It is noteworthy that in the long-term access, consumers can develop a perceived sense of ownership of objects, because the duration time brings about ownership characteristics; in fact, ownership is not real; 
2. anonymity: the form of relationship and behavior among consumers can take two different ways. In the first one, access may differ in interpersonal anonymity, as the context of the usage is private or public. In some situations, access is anonymous, since consumers have exclusive access to the object of consumption, such as cars or hotels, and do not need to interact with other consumers using the same object. In other cases, access is naturally social, as when the object is used in a public context (squares). Or still, consumption is in fact shared, as in the case of lodgings where the consumer is staying at the same time as the owner resides there (and stays during the same period);

3. market mediation: the types of access may also differ in levels of market mediation, from for profit to not for profit. Not-for-profit access-based consumption involves peer-to-peer exchange and sharing, where consumers gain access to objects and services owned by other consumers through the use of technology. Other access rely more heavily on market mediation and tend to be underlined by the profit motive of economic exchange. Examples include car sharing, online borrowing programs (Netflix), and home or room renting (Airbnb);

4. consumer involvement: this dimension is related to the level of consumer participation during consumption. They may have a limited participation, as it happens in traditional rental services (such as hotels), or great involvement, as in the case of sharing cars and other goods that may have implications related to the nature of access governance;

5. type of accessed object: two fundamental distinctions are identified here. The first one relates to the nature of access, which can vary if the object accessed is experimental (such as a painting in an art museum) or functional (such as a shared bicycle). The second one refers to the differences between material and immaterial objects. In some access contexts, the object being accessed is immaterial, especially if it has a digital format, such as music and files sharing;

6. political consumerism: this dimension represents the consumer choice as a political tool and the use of market action as an area for politics. Some consumers choose the way they consume (property versus access) as a strategy to articulate and promote their ideological interests to society, companies and government. Renunciation of ownership in order to join economic access activities can be a reflexive signaling strategy, access being a way of sustainable consumption.

Schor (2014) proposes a taxonomy based on two aspects: platform orientation (profit or non-profit) and market structure, peer-to-peer (P2P) or business-to-peer (B2P). 
In another approach, websites were analyzed and classified by their sharing model, by their activity and by the presence or absence of monetary transactions (Hamari, Sjöklint, \& Ukkonen, 2015). The mapping overview is shown in Table 1.

\section{(Table 1)}

MAP OF 254 COLLABORATIVE CONSUMPTION SERVICES

\begin{tabular}{c|c|c|c}
\hline \multicolumn{2}{c}{ Sharing model } & \multicolumn{1}{c}{ Activity } & \multicolumn{1}{c}{$\begin{array}{c}\text { Financial } \\
\text { Transaction }\end{array}$} \\
\hline \multirow{2}{*}{ Ownership access } & Renting & Yes & 131 \\
\cline { 2 - 4 } & Lending & No & 60 \\
\hline \multirow{3}{*}{ Ownership transfer } & Swapping & No & 59 \\
\cline { 2 - 4 } & Donating & No & 59 \\
\cline { 2 - 4 } & $\begin{array}{c}\text { Purchasing used } \\
\text { goods }\end{array}$ & Yes & 51 \\
\hline
\end{tabular}

Source: Adapted from Hamari et al. (2015).

The revolution in consumers' behavior online also reflects a qualitative change in their creativity called online consumer-driven innovation. This way, a model to adequately organize what was believed to be the best form of interpretation of the various online creativity practices was proposed, considering the following classifications (Kozinets, Hemetsberger, \& Schau 2008):

1. collective innovation guidance: some communities intentionally focus directed towards particular innovative results and generally delimited goals that belong to particular creations; other communities are innovative only as a kind of consequence of other online activities, often related to lifestyles, interests and hobbies, or simply the pursuit of general consumer interests;

2. concentration of collective innovation: only a few individual consumers (or even a single one) contribute with most of the input or the contribution is distributed among a large number of collaborators (many may even contribute to the project modestly, but aggregate contribution may end up adding significant value).

The academic literature reviewed provided a comparative analysis of definitions and characteristics of sharing economy and collaborative consumption, as well as it helped identifying websites examples to be used in the research. Then, a typology for sharing economy is proposed. 


\section{CRAFTING A TYPOLOGY FOR SHARING ECONOMY}

The first step in order to propose a typology consisted in identifying a set of characteristics of sharing economy and its possible occurrences, being these identifications based on studies on the characteristics of sharing economy and collaborative consumption (Table 2).

\section{(Table 2)}

\section{CHARACTERISTICS OF SHARING ECONOMY AND COLLABORATIVE CONSUMPTION}

\begin{tabular}{|c|c|c|}
\hline Characteristics & Occurrence & Reference \\
\hline \multirow{2}{*}{ Platform Type } & Interfering & \multirow{2}{*}{$\begin{array}{c}\text { Botsman and Rogers, 2010; } \\
\text { Hamari et al., } 2015\end{array}$} \\
\hline & Intermediary & \\
\hline \multirow{2}{*}{ Sharing Model } & Access & \multirow{2}{*}{$\begin{array}{l}\text { Belk, 2010; Botsman and Rogers, } \\
\text { 2010; Bardhi and Eckhardt, } 2012\end{array}$} \\
\hline & Transfer & \\
\hline \multirow{6}{*}{ Sharing Type } & Renting & \multirow{6}{*}{$\begin{array}{l}\text { Belk, 2010; Botsman and Rogers, } \\
\text { 2010; Corciolani and Dalli, 2014; } \\
\text { Hamari et al., } 2015\end{array}$} \\
\hline & Lending & \\
\hline & Swapping & \\
\hline & Donating & \\
\hline & Gifting & \\
\hline & Purchasing used goods & \\
\hline \multirow{2}{*}{ Market Structure } & Peer-to-peer (P2P) & \multirow{2}{*}{ Schor, 2014} \\
\hline & Business-to-peer (B2P) & \\
\hline \multirow{2}{*}{ Sharing Nature } & Experimental & \multirow{2}{*}{ Bardhi and Eckhardt, 2012} \\
\hline & Functional & \\
\hline \multirow{2}{*}{ Financial Transaction } & Present & \multirow{2}{*}{$\begin{array}{c}\text { Bardhi and Eckhardt, 2012; } \\
\text { Schor, 2014; Hamari et al., } 2015\end{array}$} \\
\hline & Absent & \\
\hline \multirow{2}{*}{ Sharing Duration } & Short Term & \multirow{2}{*}{ Bardhi and Eckhardt, 2012} \\
\hline & Long Term & \\
\hline \multirow{2}{*}{ Consumer Anonimity } & Possible & \multirow{2}{*}{ Bardhi and Eckhardt, 2012} \\
\hline & Impossible & \\
\hline \multirow{2}{*}{ Consumer Involvement } & Low & \multirow{2}{*}{ Bardhi and Eckhardt, 2012} \\
\hline & High & \\
\hline
\end{tabular}




\section{(Table 2)}

CHARACTERISTICS OF SHARING ECONOMY AND COLLABORATIVE CONSUMPTION

(conclusion)

\begin{tabular}{|c|c|c|}
\hline Characteristics & Occurrence & Reference \\
\hline \multirow{2}{*}{ Political Influence } & Low & \multirow{2}{*}{$\begin{array}{c}\text { Bardhi and Eckhardt, 2012; } \\
\text { Laamanen, Wahlen, Campana, } 2015\end{array}$} \\
\hline & High & \\
\hline \multirow{2}{*}{ Collective Innovation } & Oriented & \multirow{2}{*}{$\begin{array}{l}\text { Kozinets, Hemetsberger and } \\
\text { Schau, } 2008\end{array}$} \\
\hline & Concentrated & \\
\hline
\end{tabular}

Source: Elaborated by the authors.

Platform type: since collaborative consumption is largely mediated by online information systems (Hamari, Sjöklint, \& Ukkonen, 2015), one identified characteristic is platform type. Platforms that interact in the transaction have mandatory action; otherwise, the transaction does not occur. For example, if there is a financial transaction, payment issues are handled through the online platform and it manages its legal aspects (Botsman \& Rogers, 2010). These are called interfering platforms. On the other hand, other platforms do not get involved in the process, acting as a communication tool, only putting the interested parties in contact (Botsman \& Rogers, 2010). These are called intermediary platforms.

Sharing model: there are two divisions regarding the sharing model: 1. the ones that only grant access, where the customer is given only usage permission (Bardhi \& Eckhardt, 2012; Belk, 2010), and 2. the ones that can transfer ownership of goods (Botsman \& Rogers, 2010).

Types of sharing: regarding types of sharing, there are different categories that described the mode of sharing: renting, lending, swapping, donating, purchasing used goods (Belk, 2010; Hamari, Sjöklint, \& Ukkonen, 2015) and gifting (Corciolani \& Dalli, 2014).

Market structure: relates to the ownership of the goods being shared. In P2P models, sharing goods or services is performed between individuals, being one of them the sole owner. In B2P models, goods belong to a company and are shared by different individuals (Schor, 2014).

Sharing nature: it can be experimental, where consumer has an indirect experience with goods, and functional, where there is a direct experience with goods, commonly by using and touching them (Bardhi \& Eckhardt, 2012). 
Financial Transaction: the fifth characteristic identified; it relates to the existence of a financial transaction; it can be present or absent (Bardhi \& Eckhardt, 2012; Hamari, Sjöklint, \& Ukkonen, 2015; Schor, 2014).

Sharing duration: it can be a long term, denoting ownership or association, or a short term which means during shorter and determined periods (Bardhi \& Eckhardt, 2012).

Consumer anonymity: it is related to the consumer level of participation in consuming and their tendency to build a relationship. It is linked to the consumer's choice for exclusive or social involvement. There are situations when the consumer can choose not to be identified, which makes anonymity possible or impossible (Bardhi \& Eckhardt, 2012).

Consumer Involvement: it is related to the consumer's responsibility regarding consumption and their intention in participating. They can choose to have high or low levels of commitment and relationship during the process (Bardhi \& Eckhardt, 2012).

Political Influence: it refers to the consumer's choice in using consumption itself as a political tool. They can use a high or a low strategy of political promotion through collaborative choices (Bardhi \& Eckhardt, 2012; Laamanen, Wahlen, \& Campana, 2015).

Collective Innovation: it can be oriented, when consumers are focused on innovation objectives in which they get involved during consumption, or concentrated, when innovation is a greater effort of only one part of those involved in the system; usually its creators (Kozinets, Hemetsberger, \& Schau, 2008).

Later, collaborative consumer websites were analyzed and grouped based on their similarities and differences. For this, a table was prepared with the 24 categories of collaborative consumption proposed by Botsman and Rogers (2010) and, for each category, three websites were identified. The websites were selected having the ones identified in academic literature as guidelines and also examples from each category presented by Botsman and Rogers (2010). Therefore, 72 websites have been visited (Table 3).

\section{(Table 3)}

\section{ANALYZED WEBSITES}

\begin{tabular}{l|l}
\multicolumn{2}{c}{ CATEGORY } \\
\hline Car Usage & ACCESSED WEBSITES \\
\hline Car Rental & Relayrides, Getaraund, Spride \\
\hline
\end{tabular}




\section{(Table 3) \\ ANALYZED WEBSITES}

(conclusion)

\begin{tabular}{|c|c|}
\hline CATEGORY & ACCESSED WEBSITES \\
\hline Bicycle Usage & Bixi, Itaú, B-Cycle \\
\hline Shared Trips & ZimRide, GoCarShare, Karzoo \\
\hline Toy Rentals & Girafun, Rent That Toy, Baby Plays \\
\hline Book Rentals & CampusBookRentals, Gobooks, Chegg \\
\hline Fashion Items Rentals & BoBags, Fashion Hire, DressedUp \\
\hline Film Usage & Netflix, NetNow, Lend Around \\
\hline Varied Objects Rentals & Getable, Rentstuff, Rentcycle \\
\hline Online Commerce & Mercado Livre, E-Bay, Gumtree \\
\hline Exchanges & FreeCycle, Descola Aí, Xcambo \\
\hline Used Electronics & OLX, Bom Negócio, Around Again \\
\hline Used Books & Estante Virtual, Paperbackswap, Livra Livros \\
\hline Used Toys & Toy Swap, Swap it Baby, Mumswap \\
\hline Used Clothes & 99 Dresses, Retroca, BigWardrobe \\
\hline Used DVDs, CDs and Games & Netcycler, Swapsity, Swap \\
\hline Room Rental & Airbnb, Bed and Fed, Roomorama \\
\hline Service Exchange & OurGoods, BarterCard, TaskRabbit \\
\hline Crowdfunding & Catarse, Movere, Starstomegood \\
\hline Skills Sharing & Skillshare, Tradeschool, Tourboarding \\
\hline Knowledge Sharing & Techshop, 3rdSpaceStudio, Wikipedia \\
\hline Community Support & Mútuo, Toolzdo, Doare \\
\hline Rides & Caroneiros, Snappcar, Carona Brasil \\
\hline Meal Sharing & Eat With Me, HouseFed, Lourish \\
\hline
\end{tabular}

Source: Adapted from Botsman and Rogers (2010).

After designing Table 3, the next step was to classify each website according to the characteristics presented in Table 2. At first, all the characteristics we combined at the same time and it was not possible to identify clear groups from the examples in order to have a typology. Thus, different combinations of characteristics were carried out. Such combinations were performed with the purpose of verifying which of them generated more delimited groups. This, and a review of the academic literature in order to identify which characteristics were more present in the discussions and their ease 
of identification in the sites visited, helped in the identification of four characteristics to guide the typology: platform type, sharing model, market structure, and financial transaction.

Two of the analyzed characteristics in the surveyed websites converged: platform types and financial transaction. In most of the analyzed examples, when there is a financial transaction, it was from an interfering platform. In the few cases where there is the presence of financial transactions in intermediary platforms (e. g. GoCarShare), this transaction occurred directly between individuals (without platform interference). The two models of sharing: access and transfer were identified in the two market structures: P2P and B2P, but with a predominance of some as best described below. Finally, no B2P market structure was identified when there was the absence of financial transactions. Therefore, three archetypes were identified: new business models, redesigned businesses and sharing by ideal (Figure 1).

\section{(Figure 1) \\ TYPOLOGY OF SHARING ECONOMY}

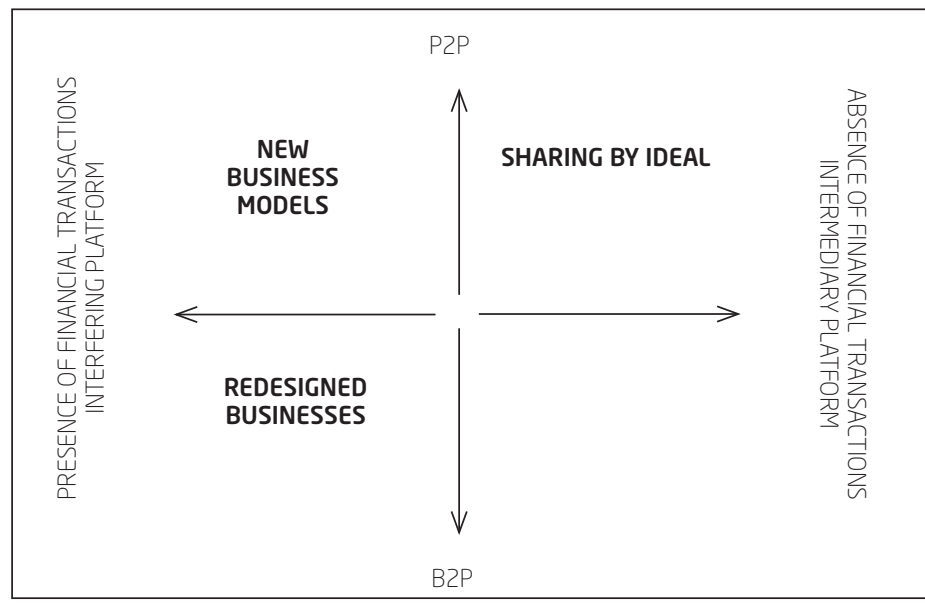

Source: Elaborated by the authors.

In all archetypes, it was possible to find examples of the three types proposed by Botsman and Rogers (2010): product service systems, redistribution markets, and collaborative lifestyles. In our analysis, the typology proposed by these authors was strongly associated to only one of the characteristics: sharing models. In the Product Services System, which 
involves the transformation of goods into service, the presence of the accesssharing model is identified. In Redistribution markets, characterized by the re-use and reinsertion of used products back on the market, the presence of the transfer-sharing model is identified. And in the collaborative lifestyles, the two sharing models are identified.

Redesigned businesses and new business models archetypes are characterized by the presence of financial transactions in interfering platforms, mas they differ in terms of market structure. While the former connects organizations with individuals, the latter connects individuals to one another.

The redesigned businesses archetype focuses on all researched cases whose market structure is B2P, highlighting such models as a reinvention of traditional market models in more flexible forms of marketing, such as ZipCar, an Avis Budget Group company, traditional in the car rental business. ZipCar is based on the car-sharing concept. Car sharing is a car rental system, just like the traditional car rental, but it offers shorter rental options where the customer rents the car for just a few hours or for a single day, at much cheaper rates, gas and insurance included. Other examples of this archetype are Netflix (movie-sharing), Estante Virtual (sale of used books) and Gobooks (book rental). This archetype is also characterized by emphasizing access as a sharing model; and few of the sites analyzed use underused assets in their business. Estante Virtual website is an exception example of this archetype since its sharing model is transfer and the assets are underused. The business proposition focuses on the re-use and reinsertion of used books, connecting second-hand bookstores to individuals.

The new business models archetype was named this way because it is clearly characterized by the emergence of new players in traditional areas, e.g. AirBnb in the tourism sector and Uber in the transport sector. In this archetype, the models of sharing, access and transfer are presented in a balanced way, being Relayrides (car rental) and Airbnb (accommodation rental) examples of access, and Ebay (sale of varied goods) and Catarse (crowdfunding), transfer examples. Business models are heavily based on technology platforms, which are the core business of business, and have their profit source in charging fees for the service provided, both in accessbased and transfer-based sharing models. As an access example, one can use Relayrides website, a car sharing solution between peers. This solution connects people who advertise their cars on the company's website and those who are looking for cars. The car owner sets the price and informs the periods in which the vehicle will be available. The website tries to connect 
those interested in using the cars that are located the closest. When renting the vehicle, $75 \%$ of the rent goes to the car owner and the rest is Relayrides' service charge. Those who rent pay to Relayrides; it passes the money on to the car owner and is also responsible for insurance in case of an accident. As a transfer example, there is Catarse website, a crowdfunding model, in which, if the requested amount of money is reached or exceeds, the project owner gets the money collected, and Catarse collects $13 \%$ of this amount, where about $4 \%$ is to pay the partner that processes the transactions and $9 \%$ is to Catarse. If the project does not meet the established goal, the website returns the contributions to the supporters, and neither the project owner nor Catarse profit from it.

The sharing by ideal archetype illustrates what Botsman and Rogers (2010) call collaborative lifestyles and it appears to be what best represents sharing as an alternative to conscious consumption. It is characterized by the absence of a financial transaction in a P2P market structure, adopting a transfer-based sharing model - for example, FreeCycle (donation offer), Livra Libro (community for exchanging used books), Swapsity (timely exchanges of goods and services) and OurGoods (knowledge exchange); or, to exemplify access, Lend Around (DVD lendings) or Wikipedia (knowledge sharing). As a transfer example, Freecycle is a donation website for items that would be discarded. Its members announce the products they wish to discard, as long as they are still in good usage conditions and the interested members request the product through the site. As an access example, Wikipedia is an encyclopedia voluntarily written by collaborators, which can be anyone. The website enables text editing by several people, providing knowledge access. This archetype comprehends models where sharing transcends the business sphere and is perceived as a way of life, considering a culture based on sharing, where consumption activities become collective actions. Therefore, it seems to gather moral economy characteristics, such as when it emphasizes friendly cooperation, helping others, mutual care, and especially sharing (Molz, 2013), which is the basis for its definition.

\section{DISCUSSION}

Our typology proposal, based on the characteristics pointed out in academic literature, identified three archetypes: sharing by ideal, new business models and redesigned businesses, reflecting a previous discussion on the true role of the sharing economy movement. 
On one hand, concerning sustainability as a result to be achieved, sharing economy (SE) serves as a guide or path (Heinrichs, 2013). It is an economic movement that supports alternative models as opposed to the conventional ones. These alternative models are driven by the increase of environmental awareness, combined with the omnipresence of the Internet (Cohen \& Kietzmann, 2014). Thus, SE can be also seen as opportunities for new business that appeal to the environmentally conscious audiences, stimulating new forms of consumption associated with consumer choice (Kopnina, 2017). Or still, there is a social and economic wave that transforms the way people meet their needs (Botsman \& Rogers, 2015). On the other hand, there are studies that seek to demonstrate that there are paths adopted by SE that seem to be indifferent to it (Martin, 2016). The author raises a controversial issue regarding the essence of SE, wondering on how far such a movement is a potential path to reach sustainability or a way to reinvent neoliberalism. More and more, the role of this "new economy" is controversial and paradoxical, since the SE models also have unintended negative side-effects that are less visible and often ignored (Verboven \& Vanherck, 2016; Zwickl et al., 2016).

Assuming that SE is a path to sustainability and a more sustainable form of consumption, it seems to us that the Redesigned businesses archetype is the one that most distances itself from this proposal, considering the motivators for its existence. According to Martin (2016), SE can be characterized as an innovation niche among socio-technical systems, decentralizing and breaking socio-technical and economic structures previously established. That is, as an innovation niche, SE must be able to transform, in a medium term, larger and more established social structures. In this sense, it does not seem to us that models whose market structure is B2P, being " $\mathrm{B}$ " a representative of organizations previously established, can be regarded as an innovation niche. Evidence to this can be found in one of the results we analyzed, in which only in $\mathrm{P} 2 \mathrm{P}$ business models directives for collective innovation can be found (Kozinets, Hemetsberger, \& Schau 2008). Additionally, in this archetype, few of the analyzed websites use underused assets in their business, which is in accordance with environmental awareness in consumption. An exception to this is Estante Virtual website, which sells used books (denoting reusing) connecting second-hand bookstores to individuals, rather than selling them directly between individuals. However, these models are still considered part of SE, because they promote resource sharing by accessing this resource for shorter periods of time and at lower prices. These advantages are essentially made possible by technological platforms, which allow a great scale gain. 
For example, in the car-sharing industry, an organization can rent the same vehicle to multiple individuals on a single day, dividing service costs among its customers more efficiently.

On one hand, the new business models archetype can be seen as a reinforcement model to the neoliberal paradigm given the fact that, in these cases, there is revenue generation for the platform, resulting in an economic opportunity (e.g. Airbnb and Uber). On the other hand, such platforms fit into an economic system of networks that provide underused goods and services that come from individuals (P2P). In this sense, the new models make collaborative offerings more convenient and seem to be necessary to allow a wide dissemination and usage of collaborative consumption. Barnes and Mattsson (2016) point out that the major motivators identified for collaborative consumption growth are economic ones, maintained by economic problems and the need to save money, as well as technological ones, by means of the dissemination of mobile devices and the Internet, and also social and cultural aspects. Unfortunately, sustainability issues do not seem to be very important for collaborative consumption these days. In other words, such businesses are not driven by concern about sustainability and conscious consumption.

Finally, these two archetypes clearly relate to issues associated to profit margin pressures in traditional business and the emergence of new business models based on technology, leading traditional organizations to move towards the SE. According to Cusumano (2014), in order to ensure their competitiveness, organizations that adopt the traditional economic model identify opportunities and adapt themselves to the needs of this connected and interactive society. Another important characteristic that is present in these archetypes is low cost related to the comprehensiveness of this global connectivity. Therefore, even with a bias clearly focused on economic activity, such types of SE enable a greater number of people to have access to a good or service. However, and perhaps paradoxically, it was the introduction of these for-profit platforms that promoted a rapid expansion of the term sharing economy.

The sharing by ideal archetype seems to be the one where the understanding of how interpersonal and cultural relationships are affected in the SE is clearer, with people sharing cultures, needs, demands, with real engagement of people, significantly shaping relationships (Zelizer, 2010). Individuals' behavior is impacted when they find emerging opportunities that generate social integration, income, and access to assets that are not available in their lives up to a given moment (Dillahunt \& Malone, 2015). 
According to Baumard, André, and Sperber (2013), people do not cooperate for the sake of it; they do it when there is a common benefit, and when they realize such benefit, they act collectively to achieve it. Cooperating for collective benefit rewards those who most help and are therefore recognized for their efforts. The more you contribute to the whole, the more value you have. Many of the websites classified in this archetype allow reuse and reinsertion of goods, not only granting access to unavailable goods, but also promoting collective benefit by reducing discarded objects, which, for the sake of society, makes sustainability a consequence of this form of consumption, since it minimizes the quantity of new products produced. That is, this archetype is the one that seems to best represent alternative models to the conventional ones, driven by the increase of environmental awareness, seeing sustainability as a result to be achieved and where the SE serves as a guide or path.

The debut of the SE came loaded with a discourse on doing good, building connections, bringing social benefits for access to goods and services and saving the environment. To the extended that some types of SE become more commercially oriented, reissuing a conventional capitalist system, they further depart from the discourse that gave rise to them. For Schor (2014), non-profit platforms usually occur (and restrict themselves) at the community level. Is it necessary to keep the original discourse that they need to remain at the level of communities? If so, will they survive? It's too early to tell. On the one hand, it may be possible to reconcile growth with a less "wild" economic view. On the other hand, the EC can turn into a co-optation of what initially seemed to be an idea of transformation and social mobilization.

\section{CONCLUSIONS}

The purpose of this study was to present a typology proposal for sharing economy, seeking to increase the understanding of the diversity of models attributed to this term, which have been emerging more and more rapidly. For this, we started from a better delimitation of sharing economy and collaborative consumption, terms frequently associated and used interchangeably.

This way, we delimited sharing economy as an economic system based on resource sharing (such as products, services, space, money, and knowledge), whether by their access or transfer, whether there is payment 
or not. Collaborative consumption seems to be within the sharing economy, more strongly delimited as an environment where resource acquisition and distribution focus on consumption. It is designed in digital platforms where participants or organizations share underused resources themselves. In collaborative consumption between individuals, they assume both the role of consumers and suppliers.

Based on the analysis of characteristics identified in academic literature and considering three of them - platform type, financial transaction and market structure, three archetypes were identified - new business models, redesigned businesses and sharing by ideal, which constitute the referential framework for the suggested typology, one of the theoretical contributions of this research. The second theoretical contribution is the definition and delimitation proposed for sharing economy and collaborative consumption.

As a contribution to practice, the proposed typology allows organizations to better understand who their competitors are and to think on how to place themselves in the sharing economy. For example, car sharing may occur not only by renting cars from companies to individuals (such as Zipcar), but also between peers, from individuals to individuals (such as Relayrides). In the latter, organizations have their core business in the technological platform that connects and intermediates the interests of those who want to rent and those who want to make their vehicle available. Although they are quite different business models - one's main asset is the car and the other's, the website; they are competitors.

Additionally, the referential framework with a typology proposal opens up other research paths. For example, as a business model approach, Estante Virtual website relates to the New business models archetype. However, it has been classified as Redesigned Businesses given its market structure, which connects organizations (second-hand bookstores) to individuals (readers). This result leads us to believe that other possible sub-typologies may be found if there is an increase in the analyzed sample.

Having organizations as the unit of analysis, which archetype has greater potential of innovation, breaking the existing social and technical structures? Are the barriers and challenges faced the same regardless the archetype? Are the side effects of access more present in some archetype? For example, people who used to use public transport would now run a Car2Go or Zipcar, which leads to an increase in carbon emissions.

Having individuals as a unit of analysis, what is the consumer profile in each archetype and how does it relate (or not) to the change of the 
sociocultural role of consumption? What conditions influence consumers' dominant values, attitudes and behavior about the two types of collaborative consumption? These may be some research questions to be investigated.

\section{REFERENCES}

Barnes, S. J., \& Mattsson, J. (2016). Understanding current and future issues in collaborative consumption: A four-stage Delphi study. Technological Forecasting and Social Change, 104, 200-211. doi 10.1016/j.techfore.2016.01.006

Bardhi, F., \& Eckhardt, G. W. (2012). Access-based consumption: The case of car sharing. Journal of Consumer Research, 39(4), 881-898. doi 10.1086/666376 Baumard, N., André, J. B., \& Sperber, D. (2013). A mutualistic approach to morality: The evolution of fairness by partner choice. Behavioral and Brain Sciences, 36(1), 59-78. doi 10.1017/S0140525X11002202

Belk, R. (2007). Why not share rather than own? The ANNALS of the American Academy of Political and Social Science, 611(1), 126-140.

Belk, R. (2010). Sharing. Journal of Consumer Research, 36, 715-734. doi $10.1086 / 612649$

Belk, R. (2014). You are what you can access: Sharing and collaborative consumption online. Journal of Business Research, 67(8), 1595-1600. doi 10.1016/j.jbusres.2013.10.001

Belk, R. (1976). It's the thought that counts: a signed digraph analysis of gift-giving. Journal of Consumer Research, 3(1), 155-162.

Botsman, R. (2015). Defining the sharing economy: what is collaborative consumption-and what isn't. Retrieved from https://www.fastcompany. com/3046119/defining-the-sharing-economy-what-is-collaborativeconsumption-and-what-isnt.

Botsman, R., \& Rogers, R. (2010). What's mine is yours. London: Collins.

Cohen, B., \& Kietzmann, J. (2014). Ride On! Mobility Business Models for the Sharing Economy. Organization \& Environment, 27(3), 279-296. doi $10.1177 / 1086026614546199$

Corciolani, M., \& Dalli, D. (2014). Gift-giving, sharing and commodity exchange at Bookcrossing.com: New insights from a qualitative analysis. Management Decision, 52(4), 755-776. doi 10.1108/MD-03-2012-0241

Cusumano, M. (2014). How traditional firms must compete in the sharing economy. Communications of the ACM, 58(1), 32-34. 
Dillahunt, T. R., \& Malone, A. R. (2015). The promise of the sharing economy among disadvantaged communities. Proceedings of the 33rd Annual ACM Conference on Human Factors in Computing Systems, Seoul, 2285-2294. doi 10.1145/2702123.2702189

Gansky, L. (2011). Mesh: Porque o futuro dos negócios é compartilhar. Rio de Janeiro, RJ: Altas Books.

Hamari, J., Sjöklint, M., \& Ukkonen, A. (2015). The Sharing Economy: Why people participate in collaborative consumption. Journal of the Association for Information Science and Technology, 67(9), 2047-2059. doi 10.1002/asi.23552

Heinrichs, H. (2013). Sharing economy: A potential new pathway to sustainability. GAIA - Ecological Perspectives for Science and Society, 22(4), 228-231.

Kennedy, J. (2016). Conceptual boundaries of sharing. Information, Communication \& Society, 19(4), 461-474. doi 10.1080/1369118X.2015.1046894

Kopnina, H. N. et al. (2017). Sustainability: New strategic thinking for business. Environment, Development and Sustainability, 19, 27-43. doi 10.1007/ s10668-015-9723-1

Kozinets, R. V., Hemetsberger, A., \& Schau, H. J. (2008). The wisdom of consumer crowds: Collective innovation in the age of networked marketing. Journal of Macromarketing, 28(4), 339-354. doi 10.1177/0276146708325382

Laamanen, M., Wahlen, S., \& Campana, M. (2015). Mobilising collaborative consumption lifestyles: A comparative frame analysis of time banking. International Journal of Consumer Studies, 39(5), 459-467. doi 10.1111/ ijcs. 12190

Malhotra, A., \& Van Alstyne, M. (2014). The dark side of the sharing economy... and how to lighten it. Communications of the ACM, 57(11), 24-27.

Martin, C. J., Upham, P., \& Budd, L. (2015). Commercial orientation in grassroots social innovation: Insights from the sharing economy. Ecological Economics, 118, 240-251. doi 10.1016/j.ecolecon.2015.08.001

Martin, C. J. (2016). The sharing economy: A pathway to sustainability or a nightmarish form of neoliberal capitalism? Ecological Economics, 121, 149159. doi 10.1016/j.ecolecon.2015.11.027

Mohlmann, M. (2015). Collaborative consumption: determinants of satisfaction and the likelihood of using a sharing economy option again. Journal of Consumer Behaviour, 14, 193-207. doi 10.1002/cb.1512

Molz, J. G. (2013). Social networking technologies and the moral economy of alternative tourism: The case of Couchsurfing.org. Annals of Tourism Research, 43, 210-230. doi 10.1016/j.annals.2013.08.001 
Mont, O. (2004). Institutionalisation of sustainable consumption patterns based on shared use. Ecological Economics, 50, 135-153. doi 10.1016/j. ecolecon.2004.03.030

Piscicelli, L., Cooper, T., \& Fisher, T. (2015). The role of values in collaborative consumption: Insights from a product-service system for lending and borrowing in the UK. Journal of Cleaner Production, 97, 21-29. doi 10.1016/j. jclepro.2014.07.032

Schor, J. (2014). Great Transition Iniciative. Retrieved from www.greattransition. org/publication/debating-the-sharing-economy

Sherry Jr. J. F. (1983). Gift giving in anthropological perspective. Journal of consumer research, 10(2), 157-168.

Silveira, L. M., Petrini, M., \& Santos, A. C. M. Z. (2016). Economia compartilhada e consumo colaborativo: o que estamos pesquisando? Revista de Gestão, 23(4), 298-305. doi 10.1016/j.rege.2016.09.005

Verboven, H., \& Vanherck, L. (2016). The sustainability paradox of the sharing economy. UmweltWirtschaftsForum, 24(4), 303-314.

Zelizer, V. A. (2010). Economic lives: How culture shapes the economy. Princeton, NJ: Princeton University Press.

Zwickl, K., Disslbacher, F., \& Stagl, S. (2016). Work-sharing for a sustainable economy. Ecological Economics, 121, 246-253. doi 10.1016/j. ecolecon.2015.06.009

\section{ABOUT THE AUTHORS}

\section{MAIRA PETRINI}

$\mathrm{PhD}$ in Business Administration, from São Paulo School of Business Administration (EAESP).

Fundação Getúlio Vargas (FVG).

Full professor at the School of Business,

Pontifícia Universidade Católica do Rio Grande do Sul (PUC-RS).

Av. Ipiranga, 6681, Partenon - Porto Alegre - RS - Brasil - CEP 90619-900

E-mail maira.petrini@pucrs.br

\section{CÁSSIO STEDETN DE FREITAS}

Master degree in Business,

Pontifícia Universidade Católica do Rio Grande do Sul (PUC-RS).

Vice President at the

Project Management Institute.

Av. Ipiranga, 6681, Partenon - Porto Alegre - RS - Brasil - CEP 90619-900

E-mail: stedetn@hotmail.com 


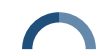

Maira Petrini, Cássio Stedetn de Freitas, Lisilene Mello da Silveira

\section{LISILENE MELLO DA SILVEIRA}

Master degree in Business,

Pontifícia Universidade Católica do Rio Grande do Sul (PUC-RS).

Professor at the Department of Management,

Instituto Federal do Rio Grande do Sul (IFRS).

Estrada João Viterbo de Oliveira, 3061 - Área Rural - Vacária - RS - Brasil - CEP 95200-000

E-mail: lisilene.silveira@hotmail.com 